\title{
Gultura.jor
}
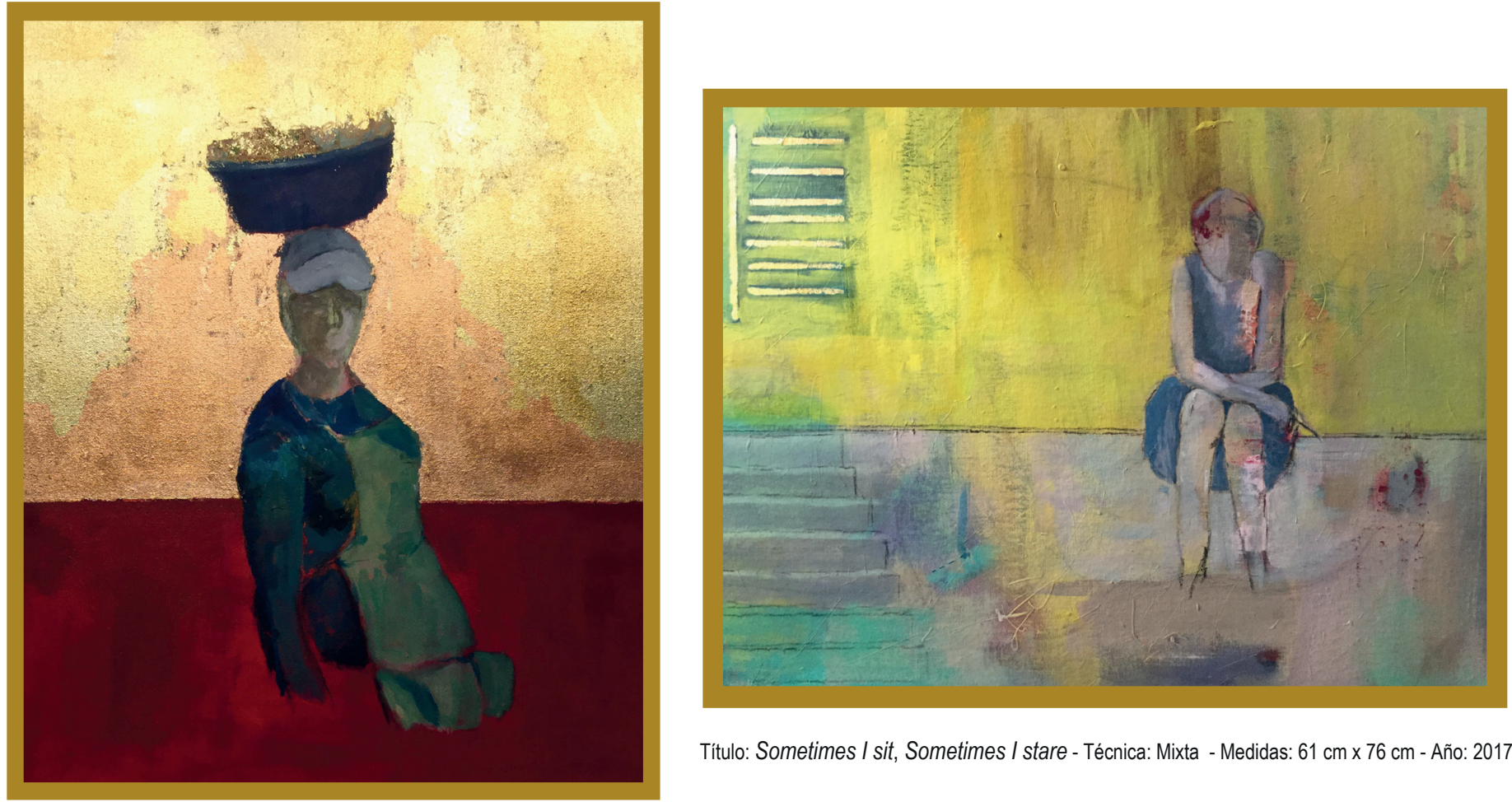

Título: Sometimes / sit, Sometimes / stare - Técnica: Mixta - Medidas: 61 cm x 76 cm - Año: 2017

Título: La Vendedora - Técnica: Mixta - Medidas: 50 cmx 61cm - Año: 2017

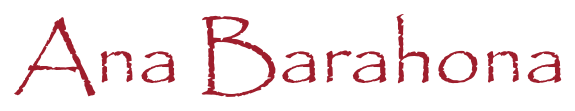

Soy estudiante de Arte en Open College of the Arts (UK). He realizado cursos en Academy of Art University de San Francisco, CA y estudiado bajo la tutela del Maestro Róger Pérez de la Rocha (Nicaragua). Recientemente, he participado en exposiciones colectivas con otros artistas nicaragüenses.

Comencé dedicada al retrato en carboncillo, pero ahora me concentro en la exploración del color y los diversos materiales que utilizo en mis pinturas, en su mayoría abstractas.

Las posibilidades con los materiales y los colores son infinitas. No puedo decidir por una técnica en particular. Cada línea, cada trazo, es un paso más a un descubrimiento personal. Soy un artista emergente que busca explorar la vulnerabilidad de nuestras experiencias humanas, la naturaleza que nos rodea, y como nos afectan a través del arte.

\section{Ana Barahona}

Artista plástica nicaragüense 